\title{
HER MAJESTY'S COLONIAL SERVICE LEPROSY SERVICE IN NIGERIA
}

Medical Officer required for the administration of preventive medical services and the clinical work of curative medicine in relation to leprosy. The selected officer would not deal with leprosy only but would also have the general medical and surgical care of leprosy patients. $\mathrm{He}$ would be stationed at a Settlement with properly equipped hospital (with Nursing Sister) and laboratory. The work also includes the supervision of leprosy segregation villages and treatment centres within a radius of 100 miles; making epidemiological investigations; and teaching African Staff. Clinical research work is encouraged. The officer will normally have professional colleagues and live in a European community.

Appointment may be made as follows:-

(a) on 3 years probation for permanent and pensionable employment in the Colonial Medical Service, with retiring age of between 45 and 55. Pensions are at the rate of I/6ooth of final pensionable emoluments for each completed month of reckonable service.

(b) ' from the National Health Service.

Candidates may resign from the National Health Service but retain their superannuation rights during their time in Nigeria (up to six years) and receive a resettlement grant of $20 \%$ of the aggregate of their Colonial salary on leaving Nigeria at the end of their engaigements.

or (c) on short term contract with inclusive salary of from $£ \mathrm{I}, \mathrm{I} 64$ per annum rising to $£ 2$, I50 per annum; on completion of contract a gratuity is paid at the rate of $£ 37$ Ios. od. for each completed period of 3 months service (including leave).

Officers appointed under (a) or (c) are required to contribute to a Widows' and Orphans' Pension Scheme.

Salaries for officers appointed under (a) or (b) range from $£$ I,010 to $£ I, 850$ per annum. Starting salary in all cases depends on age, experience and war service.

Quarters are provided at low rents. Free passages for officer and his wife and assisted passages for up to two children under the age of I6. Income tax at lecal rates. Normal tour of service is I8 months. Generous home leave. Candidates must hold medical qualifications registrable in the United Kingdom. Application forms can be obtained from the Director of Recruitment (Colonial Service), Colonial Office, Sanctuary Buildings, Great Smith Street, London, S.W.I. (quoting reference CSE 60/I4/oI). 